\title{
"All That's Left is Bare Land and Sky": Palm Oil Culture and Socioenvironmental Impacts on a Tembé Indigenous Territory in the Brazilian Amazon
}

\author{
Sandra Damiani \\ Silvia Maria Ferreira Guimarães \\ Maria Tereza Leite Montalvão \\ Carlos José Sousa Passos
}

${ }^{I} \mathrm{MSc}$ in Sustainable Development, University of Brasília-DF, Brazil.

"I PhD in Anthropology, Professor at the Department of Anthropology, University of Brasilia, Brasília, DF, Brazil.

${ }^{\text {III }} \mathrm{MSc}$ in Forest Sciences from the University of Brasília, BrasíliaDF, Brazil

${ }^{\text {IV }} \mathrm{PhD}$ in Environmental Sciences, Associate Professor at the Faculty UnB Planaltina, University of Brasília, Brasilia-DF, Brazil.

\begin{abstract}
The expansion of large-scale oil palm cultivation in the Amazon has exposed indigenous populations to changes around their lands and in their daily activities. Given the lack of studies on the impacts of oil palm on these populations, this study analyzed the socioenvironmental impacts perceived by the Tembé, in Tomé-Açu, Pará State. With an interdisciplinary approach, between 2016 and 2017, semi-structured interviews and participant observation were conducted in five villages, inside and adjacent to the Turé-Mariquita Indigenous Land and complemented by remote sensing analyzes. This article describes the pressure vectors and the main socio-environmental impacts through the analysis of the indigenous narrative, and then these are discussed based on the scientific literature and remote sensing data. The findings indicate that the conversion of the surrounding territory to oil palm monoculture generated social and environmental changes that negatively affected the Tembé's way of life and their capacity of socio-cultural reproduction.
\end{abstract}

Keywords: Socio-environmental impacts, oil palm, indigenous land, Tembé people, Brazilian Amazon.

São Paulo. Vol. 23, 2020

Original Article

DOI: http://dx.doi.org/10.1590/1809-4422asoc20190049r2vu2020L6AO 


\section{Introduction}

In little more than ten years, the Brazilian Amazon has seen an unprecedented expansion in African Palm (Elaeis guineensis) oil production boosted by the growing demand from the food, cosmetics and biofuel sectors of internal and external markets (VILLELA et al., 2014). However, the peak in the cultivation of this oil-producing species in the Amazon, under the aegis of regional sustainable development, has become shrouded in controversy due to indications of its socio-economic impacts on local and indigenous population groups living in the vicinity of the plantations (GLASS, 2013; MPF, 2014).

Stimulated by federal government policies such as the National Program for the Production and Use of Biodiesel (Programa Nacional de Produção e Uso de Biodiesel PNPB), created in 2005, the Sustainable Oil Palm Production Program (Programa de Produção Sustentável de Palma de Óleo - PPSPO) and the Palm Oil Agroecological Zoning (Zoneamento Agroecológico do Dendê - ZAE-Dendê) launched in 2010, the planted area of this crop in the state of Pará increased by more than 200\% in the years from 2006 to 2014, occupying 219 thousand hectares (BENAMI et al., 2018) and concentrating 90\% of Brazilian palm oil production (FAPESPA, 2017).

To avoid harming the forests, biodiversity and local populations in the way that has happened in Malaysia and Indonesia, the world's biggest palm oil producers (WILCOVE; $\mathrm{KOH}, 2010$; OBIDZINSKI et al., 2012), the policy designed to stimulate the crop's expansion in Brazil stipulated that palm oil cultivation should be mandatorily restricted to degraded areas and that deforestation should be forbidden. The regulations of the PPSPO, whose draft bill $7326 / 10$ is still being processed, do not permit its cultivation in indigenous lands or protected areas but there are no regulations specified for the areas surrounding them. In the state of Pará, oil palm cultivation is considered to have 'low polluting/degrading potential' and so it can take place under a simplified licensing process ${ }^{1}$.

Recent research has addressed the transformation of rural spaces, changes in the agricultural practices of local communities and the gains and losses experienced by family-based agriculture that adopted oil palm cultivation (NAHUM; SANTOS, 2017; MOTA; SCHMITZ, 2019). There is a scarcity of empirical studies of the possible socioenvironmental impacts on Amazonian indigenous populations stemming from oil palm cultivation.

In Tomé-Açu (Pará) indigenous people of the Tembé ethnic group have reported damage associated to the transformation of the territory surrounding their villages into single crop plantations of this oil-bearing species (FUNAI, 2014) and the geographic dimension of that territorial dispute has been analyzed by Nahum and Thury (2015). On the other hand, there is a broad discussion in course on development projects' impacts on indigenous territories or lands belonging to traditional communities (MILTON, 1993; LITTLE, 1999) and the palm oil production project precisely fits into that category.

1- Simplified licensing can dispense with prior inspection, with licenses (Prior, Installation and Operation) being issued with the electronic submission of the Term for Aknowledgment and Responsibility as well as other documents required by Resolution No. 127/2016, among which the Registry Environmental Rural (CAR) (COEMA, 2016; CODEC, 2020). 
Thus, this article analyzes the Tembé's perception of the socio-environmental pressures and impacts that arose in the wake of the establishment of oil palm cultivation in the areas surrounding the Turé-Mariquita Indigenous Territory and the two adjacent villages. It discusses the data gathered among the Tembé regarding the changes that have occurred and their influence on the way of life, wellbeing and socio-cultural reproduction of this people and triangulates them with remote sensing data and the respective scientific literature.

The intention behind relating the western, scientific narratives is not to confirm the data the Tembé have gathered, but, instead, to instigate a dialogue of knowledges which in many situations challenge one another, producing a duality between the hegemonic and the subaltern, the traditional and the scientific. The power of the Tembe narrative, is a source of innovation for western scientific thinking (CARNEIRO DA CUNHA, 2009).

\section{Study population and locality}

The study was unfolded among the people of the Tembé ethnic group who live in three villages within the limits of the Turé-Mariquita Indigenous Territory (IT) and in two other nearby villages in the municipality of Tomé-Açu, around $200 \mathrm{~km}$ from Belém (Figure 3). A bauxite transportation pipeline cuts right across the 734.8 hectares of the IT (FUNAI, 2014). The two villages outside the IT have areas of 25 and 50 hectares and a total of 135 Tembé people live in the two villages and the IT. The Tembé people communicate with one another in Portuguese but they seek to acquire/retain fluency in their native language, Tenetehara, of the Tupi-Guarani linguistic family. Their diet is mainly based on manioc/cassava, rice and beans that they either grow in their fields or buy in local shops. They raise small animals and hunt for game. They collect a variety of fruits in the IT forests and surrounding areas and from fruit trees planted in their fields. Some of the families plant black-pepper and it is an important source of income for them.

\section{Methodological Procedures}

This qualitative research is directed at identifying the meanings, interpretations and presentations produced by the study subjects (MINAYO, 2010) and it is based on ethnography (PEIRANO, 2008). In other words, after data collection and establishing dialogues with the study subjects in the field, it sought to elaborate an ethnographic theory, referenced by the Tembé narrative, regarding the vectors of socio-environmental pressures and impacts on the lives of the Tembé people.

Remote sensing techniques were also used to identify landscape changes in the course of time in the areas surrounding the IT. Data gathering was done by means of participant observation, field diary notes, informal conversations and structured or semistructured interviews (ANGROSINO, 2009; SABOURIN, 2016). The field work consisted of a pre-fieldwork visit in June 2015 and two field trips: one in October/November 2016 and the other in January/February 2017.

The leading researcher stayed in the IT and visited five villages to hear what 
their leaders had to say and, as is usual in ethnographic research, new interviewees were identified, according to the nature of the research questions. Altogether 30 indigenous people of Tembé ethnic group, two employees of the National Indian Foundation (Fundação Nacional do Índio - FUNAI) and two health agents were interviewed. The Tembé persons who were interviewed are not identified by name in this research for their own protection. The research was duly approved after submission to the UnB Research Ethics Committee (Process №62508816.6.0000.5540).

Data handling involved the steps of content description, analysis and interpretation as described by Minayo (2010), and schematically represented in Figure 1 below.

\section{Figure 1 - Steps in the qualitative data treatment}

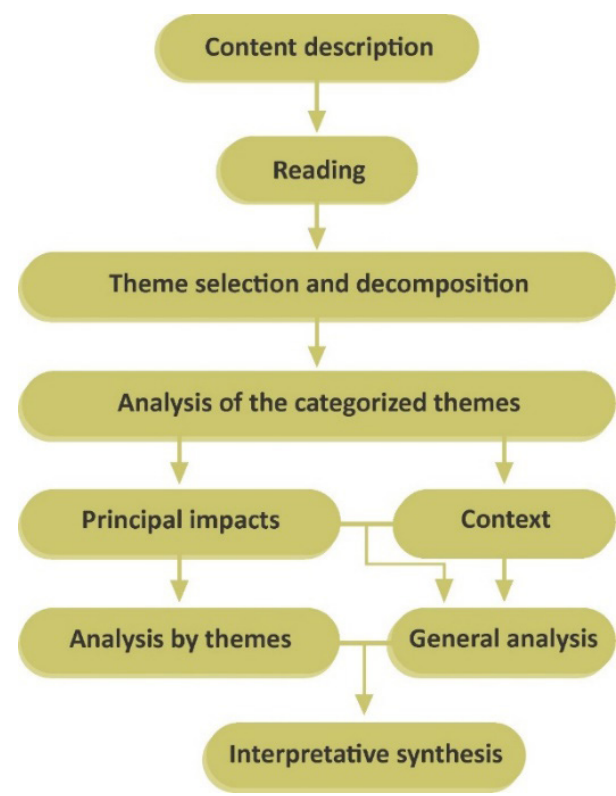

Source: Elaborated by the authors, 2017.

All the collected material was transcribed and subjected to a careful reading. That process, which involves the decomposition of the gross transcribed contents, thematizing, and analysis of the emergent themes, led to the identification of the main impacts. The main impacts were then decomposed into themes. The general analysis was designed to obtain the context of the Tembés' lives in the midst of the palm plantations. Lastly, the interpretative synthesis led to the creation of the text presented in this article.

\section{Mapping of the Indigenous Territory and the surrounding areas}

The acquisition of information regarding the environmental characteristics of the IT and the surrounding areas was achieved by: i) in loco observation; ii) obtaining information 
from Tembe leaders with the support of a printed map; and iii) registering the geographic coordinates in the field with the help of the Tembe themselves, and analysis of remote sensing data aggregating spatial analysis data to the indigenous perception indicators.

Remote sensing techniques were used to define dimensions of the areas converted into oil palm plantations and deforested areas for the period 2008 to 2014 within the range of $5 \mathrm{~km}$ from the IT limits.

Definition of the different classes of land use was based on satellite images ${ }^{2}$ of the region. After initial treatment with ArcGIS $10^{3}$ software the images were processed for atmospheric correction and that made it possible to apply supervised classification.

The classification of the deforested areas was further refined with the classification system of the PRODES project (Satellite Monitoring of Brazilian Amazon Deforestation) which produces data on annual deforestation rates. The areas classified as oil palm plantations were compared with data of the TerraClass project (Inpe and Embrapa) for the years 2004, 2008, 2010, 2012 and 2014 to identify areas in natural regeneration.

In the validation process it was found necessary to use Rapideye images, with their better spatial resolution ( $5 \mathrm{~m}$ pixel), together with the GPS registrations made in the field. Lastly a map was generated showing the areas with oil palm cultivation and the areas that had been deforested. The cartographic base used data made available by FUNAI and the IBGE, in addition to the information obtained during the fieldwork.

\section{Results and discussion}

The main socio-environmental impacts that emerged from the analysis of the Tembé narrative were divided into five groups to be discussed, as follows: i) impacts on biodiversity - loss of native vegetation in the surrounding areas, reduction in species richness and abundance of animals and the proliferation of insects and snakes; ii) impacts on waterbodies - degradation of the streams; iii) impacts on the population's health - risk of environmental contamination and the occurrence of health problems; iv) impact on the micro-climate - higher temperatures in the villages and the neighboring areas; and v) impacts on their control over the land - a feeling of insecurity; increased logging activity and the occupation of areas near to the IT by squatters and the increased pressure of hunting on the remaining forest fragments.

\section{Temporal trajectory of the impacts}

In temporal terms, the impacts that the Tembé identify are associated to anthropic actions for the implantation and management of oil palm monoculture responding for the impacts that were perceived immediately and others that were perceived as the cultivation

2. Landsat 5, TM sensor images for the years 2008, 2009 and 2010 were used with a resolution of $30 \mathrm{~m}$, and Rapideye, ETM+ sensor images for the years 2011, 2012, 2013 and 2014, with a resolution of $5 \mathrm{~m}$.

3 - The images were processed for projection adjustments using SIRGAS 2000 and its red, green and blue bands were combined in RGB to form a single image for each year. 
became consolidated. That the beginning of the changes was concomitant with the actions of the venture, as the interviews indicated, was confirmed by documents and news reports on the Tembés' demands for the interruption of agrochemical use and protests about the possible contamination of the waters (ÍNDIOS, 2012; FUNAI, 2014; MPF, 2014). The perceived impacts persisted throughout the period of consolidation of the plantations but with alterations in their intensity, outreach and characteristics. Figure 2 illustrates the cycle referring to the first area converted to an oil palm plantation.

Figure 2 - Temporal scale for the beginning of the impacts perceived by the Tembe people according to the anthropic actions resulting from oil palm cultivation.

Deforestation,

soil preparation

Intensive

and road building

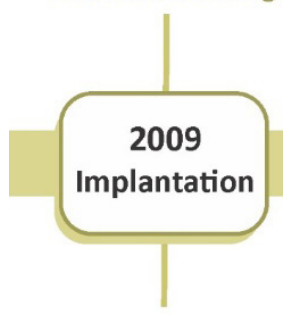

Vegetation
loss

Biodiversity

loss

Changes to
the streams
Changes in the
microclimate
"Hotness"
Less control over
the territory

agrochemicals use

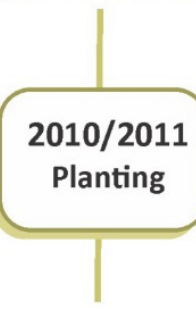

Health problems and contamination risks

Proliferation

of snakes

and insects

Source: Elaborated by the authors, 2017.

Loss of native vegetation in the surrounding lands - "It was pastureland, thickets, there were woods; it was not like this at all, oh no!"

According to the Tembé, the first impact on the villages from the oil palm cultivation was at the beginning of 2009 when the native vegetation was cleared, and the soil was exposed in vast areas of the surrounding land. The monoculture fields extended right up to the limits of the Indigenous Territory with no allowance for a buffer zone. The land around the IT borders which formerly belonged to various proprietors became concentrated in the hands of three agro-industrial farming enterprises for the purpose of palm oil production (NAHUM; THURY, 2015). The Tembé were able to tell us the story of that economic front occupation and the environmental transformations that marked it. 
Prior to the advent of the oil palm cultivation, the lands surrounding the IT were the object of a variety of land use forms in which abandoned pastureland, fields and patches of Terra Firme forest and Varzea forest in stages of primary regeneration predominated. One Tembé woman described it as follows: "It was pastureland, thickets, there were woods; it was not like this at all, oh no. We felt the change after the planting (...) What I know is that it became something very serious for us."

Corroborating that Tembé narrative, the satellite image analysis showed that between 2008 and 2014, 2,287.8 hectares of the land within $5 \mathrm{~km}$ of the IT boundaries were converted to oil palm cultivation (Figure 3). Albeit predominantly installed in previously deforested land, the plantation suppressed 333.8 hectares of secondary forest in regeneration in three blocks adjacent to the indigenous areas which they had formerly been using for hunting and gathering.

Figure 3 -Surrounding areas with land use converted to oil palm cultivation and deforested areas of former secondary vegetation within a $5 \mathrm{~km}$ range of the Turé-Mariquita IT boundaries in 2014

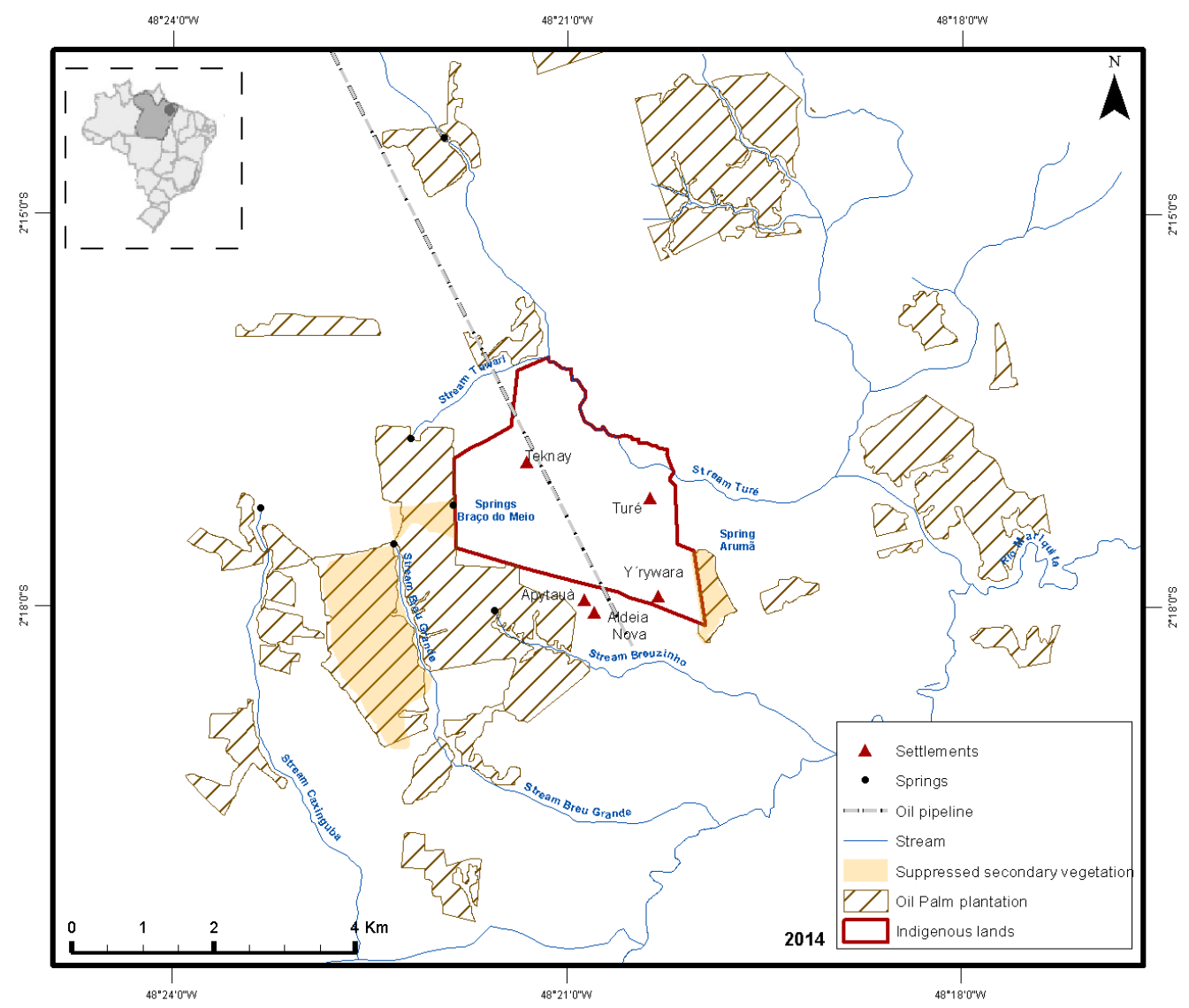

Source: IBGE, INPE - Landsat 5 images TM (2008, 2009 and 2010) and Rapideye ETM+ (2011, 2012, 2013 e 2014) and INPE/Embrapa Terraclass (2004, 2008, 2010, 2012 e 2014). Elaborated by: Maria Tereza Leite Montalvão. 
According to the Tembé, the forest land consisted of fragments of secondary forest in various stages of regeneration.

"It was all very fast. They started to break up (the forest) in July/August but there were so many machines. They piled it up, in a few days it dried out and they set fire to it. When I saw what had been done; they had cleared everything. All that's left is bare land and sky." (Tembé leader).

Secondary forest is an important habitat for mammal and bird species (PARRY; BARLOW; PERES, 2007; MOURA et al., 2013). The patches of thicket vegetation in the areas nearby the IT fulfilled that role. Part of those deforested areas had formerly made the connection with other remaining forest stands nearby.

The increase in fragmentation of natural habitats associated to the clearance of the vegetation and the change in land use bring with them adverse effects on the ecosystem services those areas provide such as biodiversity conservation, protection of water cycles and climate regulation (LAURANCE et al., 2011; GRIMALDI et al., 2014). The Tembé narrative attributes a central role to removal of the natural vegetation in the generation of negative impacts among other impacts associated to it that emerged, such as the degradation of the watercourses and the loss of biodiversity described below.

The local-level data converge with those obtained on the national scale. Using different methods, Vijay et al. (2016) have calculated that between 1989 and 2013, $39 \%$ of the areas dedicated to oil palm cultivation were areas that had been deforested whereas Benami et al. (2018) reported a figure of $8 \%$ conversion of forested areas in the period 2006 to 2014. That loss of forest land has implications in different scales regarding the possible losses of locally essential ecosystem services and the carbon emissions onus, as opposed to the carbon capture that was originally supposed to be obtained with the recuperation of degraded areas.

Government sponsored initiatives such as the PPSPO and the ZAE-Dendê have proved to be entirely insufficient to avoid deforestation because they do not have the force of law and their main preventative measure is that they merely forbid such plantations inside indigenous lands and Protected Areas. In that respect, they fail to consider the interdependence of such protected areas with the lands that surround them.

The remaining forest stands and the areas of forest vegetation in former pastureland are the ones that tend to be suppressed, insofar as they make the management process cheaper. Vieira et al. (2014) and Carvalho et al. (2015) have suggested complementary measures such as defining criteria for the classification of degraded areas, creating incentives for the protection of natural regeneration, fostering restauration actions, and policies for monitoring the areas of converted land use. Establishing buffer zones and greater strictness in licensing processes are also much needed public policies.

Biodiversity Loss - "I don't know where all the game has gone”

The Tembé describe the harm done to biodiversity that has affected their access 
to game animals as a source of food. The reduction in the abundance and diversity of animals was immediately perceived as a result of the loss of their habitat through the establishment of the plantations.

As soon as they cleared the land and the forest disappeared altogether, everybody wondered; where are we going to hunt now? Where we used to hunt there will be no woods anymore, only the bare ground (...). The game animals have gone. I don't know where. They've disappeared. (Tembé woman).

Areas where forest vegetation is regenerating, such as those suppressed near to the IT, function as biodiversity corridors, reestablishing the connectivity of natural habitats and ecosystem services in fragmented environments, and facilitating the transit of animals (VIEIRA et al., 2014). The increased degree of fragmentation and the difficulty imposed on animals' movements are described by one of the leaders as follows:

We used to see plenty of game in that big area of thicket vegetation. Birds... there were lots of them. When they opened it up, that was it. Now you can't even see a bird there. Because for them to fly from one wood to another... it's a long way [woods inside and outside the IT interspersed among the oil palm areas] The birds stay wherever there is plenty of forest.

That statement is aligned with the results that Lees et al. (2015) obtained when they showed that the bird populations associated to oil palm plantations are not very diverse and closely resemble those associated to pastures for beef cattle; they do not offer an appropriate habitat for most forest-dwelling species. There have also been reports of the reduction of biodiversity in areas of oil palm monoculture for other fauna groups mammals, amphibians and invertebrate species -, in Brazil, in Malaysia and in Indonesia (MADDOX et al., 2007; EDWARDS et al., 2011; CORREA et al., 2015).

Once the oil palms had begun to bear fruit, some generalist species began to come back. It was observed that the animal most captured to be eaten was the 'paca' (Cuniculus paca). However, the species suffered perturbation from the presence of machinery and the applications of toxic agrochemicals, among which are herbicides applied four or five times a year to eliminate vegetation that grows around the palm trees (GOMES JUNIOR, 2010).

Accounts of alterations in the local fauna, however, lack complementary studies. Animals found dead in the areas surrounding the IT in the initial years of plantation installation (e.g. fish, armadillos, alligators) and others observed with their fur or spines falling out (foxes and porcupines) make the local residents uneasy in regard to the possible causes and the possible associated risks to the population. The Tembe report how fish have become scarcer and more meagre ('mirrados' is their word) with the environmental 
changes in the streams observed after the planting stage was finalized.

Biodiversity loss has generated negative impacts on the Tembé way of life, since, traditionally, they have used the areas surrounding the IT for hunting, fishing and gathering. It must be underscored that the territory the Tembé used went beyond the IT boundaries and encompassed those areas which today are dedicated to oil palm monoculture. Those activities accompanied the circulation of the animal species and the forested areas. Thus, the changes in land use patterns in those areas led to a greater scarcity of forest-based food resources, a reduction in the families' consumption of game meat, fish and fruits and the notable advent and presence in their diet of industrialized food purchased in the 'shops'.

The forest vegetation in the extended area outside the IT is also important for obtaining wood for their dwellings and gathering other non-wood forest products such as herbs, honey, lianas/vines for producing useful objects, seeds for handicrafts and fruits (PARÁ PIGMENTOS, 1995). In the patches of forest now transformed into plantations, they used to collect fruits such as the pequiá (Caryocar villosum), the uxi (Endopleura uchi), the bacuri (Platonia insignis) and the bacaba (Oenocarpus bacaba) mainly as food but also occasionally to obtain income. That traditional use, already previously limited by rapid anthropization, has now become even more restricted.

Less control over the territory: transportation infrastructure as a pressure vector - "with good roads, it is easy to remove the timber".

The Tembé identify transportation infrastructure for the implantation of oil palm cultivation as the cause of various perturbances insofar as it constitutes a vector for the socio-environmental pressures perceived by the indigenous people. Work on those logistics structures began in 2008 and took the form of: expanding the existing roads inter-connecting cities connecting the plantation area with the state capital, Belém; and setting up a network of formerly non-existent branch roads that are present throughout the plantation area. The Tembe's analysis suggests the existence of isolated impacts and joint impacts with consequences for the physical, biotic and anthropic media.

All of the land converted for oil palm cultivation right up to the limits of the IT and previously occupied by various forms of land use with little access for vehicles, was divided up by a symmetrical network of roads between the blocks of cultivated land where the palm trees are planted, in a system designed to facilitate plantation management. Prior to the oil palm venture, the only access to the area was a dirt road, the Mariquita branch road coming from the PA140 state highway via the Quatro Bocas district.

The Tembé recall that formerly there was little movement of people, only members of the villages and other nearby communities, but the expansion of existing roads and the opening up of new ones has led to the improvement and expansion of another route passing through the IT and it has become the new route to the state capital. 
said, so many roads in every direction. What's going on? Lots of cars, lots of tractors. It was a shock to see all that happen so fast (...) I didn't believe a company that big would ever arrive here, near to us and it was right up to the limits. Right over there the oil palm begins already (Tembé leader).

For the Tembé, the expansion of the roads network between the cities brought changes to their way of life, some positive and some negative, in their view. They acknowledge that the roads have facilitated their trips to urban centers but, on the other hand, they describe how the roads have set in chain a series of negative impacts on the IT and brought with them greater exposure of the villages and a generalized feeling of insecurity. One Tembé woman expressed it in these terms:

They said they were going to put a guard to ask people where they were from, where they were not from. In the end though, they did not keep their word and they made many accesses from all directions. So now if someone commits a crime in Quatro Bocas, if they want to get away, they can go anywhere. To Belém, to Acará, to Moju (...) That was something really wrong, what the company did to us. So, we no longer live in peace, no longer live unconcerned as we did before.

The access roads in the oil palm areas also gave access to the remaining forest fragments in the surroundings. The result observed in loco, has been an intensification of logging and trading in wood, which already existed, and the advent of squatters. There is a vigorous local business trading in fence posts and poles for black pepper vine cultivation. As one of the Tembe leaders put it "with good roads installed, it is so much easier to take out the wood". There are many studies on the Amazon registering the fact that new roads are a vector for deforestation (SOARES-FILHO et al., 2005).

The Tembé also describe how opening up branch roads near to the streams and the channeling and filling in of stretches of the watercourses in the plantation area, together with the constant transit of machinery has had negative consequences for the quality of water in the springs and streams and for biodiversity (Figure 4).

Those pressure vectors have fostered the silting up of the streams and intensified erosion in the rainy seasons. During field observations by a FUNAI team, they identified stretches of underground channels in which the waterflow was totally or partially blocked as a result of erosion processes (FUNAI, 2014). The installed dams reduce aquatic connectivity and the mobility of aquatic organisms (LEAL et al., 2017). In addition, the use of machinery disturbs the terrestrial fauna.

The clearing of the vegetation carried out by the company to mark the boundaries of the IT cut off and exposed patches of forest that had formerly been in con- 
tinuity with the vegetation in the surroundings. Studies of the effects of that border indicate an increase in vulnerability to extreme events (droughts, high winds and fires), death of tree species, and restriction of the movements of forest fauna species in the vicinity of those lines of contact. If the vegetation had been maintained, then the adjacent areas in regeneration would have tended to ameliorate the effects of the IT's forest fragmentation and isolation (LAURANCE et al., 2011).

Degradation of the streams - "It all turned into that horrible mud, that mass of dead leaves, and the fish finished"

The Tembe perceived the alterations that took place in the environmental quality of the streams as soon as the planting stage was over. One of the effects of clearing the land of vegetation is the intensification of erosion processes and, depending on the nature of the soil, the angles of the slopes and the rainfall pattern, among other variables, greater or lesser quantities of soil can be carried away by the runoff (SÁNCHEZ, 2013). The indigenous people believe that silting up caused by exposure of the naked soil, the building of the roads and damming of the watercourses by blocked channels (Figure 4), together with environmental contamination associated to the use of toxic agrochemicals and fertilizers in the plantation are the main causes of the degradation of the streams.

Six of the stream headwaters used by the Tembé people are located outside the IT limits and four of those are inside the areas planted with oil palm. The local relief is largely flat with sloping ground alongside the watercourses. The implications of the initial stage of the planting process for the water resources were described by one Tembé leader as follows:

The stream would take from 8 to 10 days for the water to clear because the whole area had been plowed and, at the beginning, they applied a lot of fertilizer. That was the time when a lot of strange mud began to form in the stream beds upstream, and, when we bathed in that water, we began to notice that it caused itchiness. 
Figure 4 - (A) Leaders reported the silting up of the streams during implantation to FUNAI in 2011; (B) In 2014, leaders show FUNAI technical staff how the Turé stream was dammed up to allow for road construction; (C) oil palm monoculture comes right to the edge of the IT boundary; (D) Spring of the Arumã stream inside a forested area.
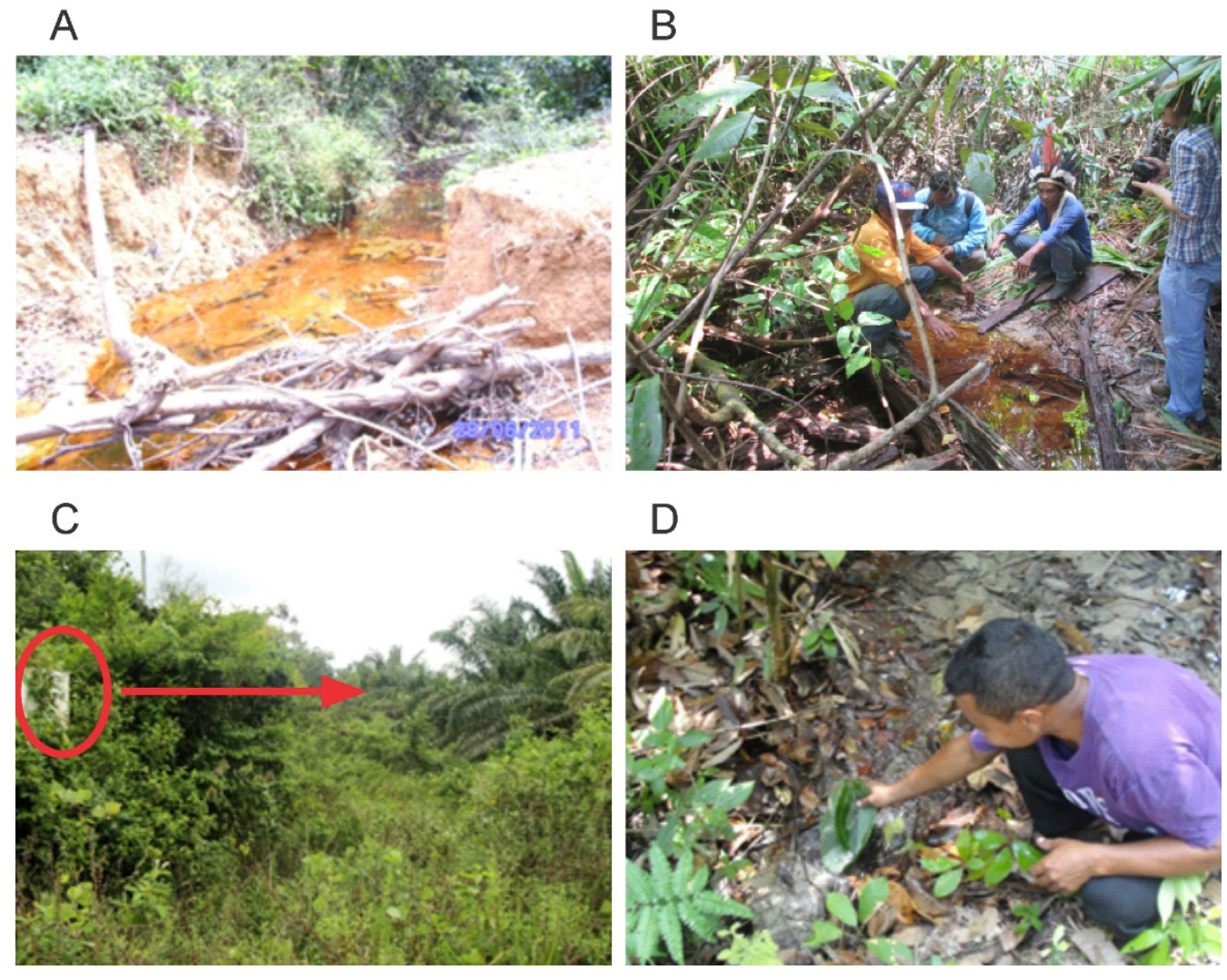

Sources: Funai (2014) and research images.

When comparing the period prior to the establishment of the oil palm cultivation and posterior to it, the main changes the Tembé perceive are the reduction in the stream flows and the changes to the properties of the water itself. They mention its yellow color, turbid aspect, smell, higher temperature, and the presence of mud and of an orangecolored substance on the surface of the water and the soil (Figure. 5). They notice that streams flow more slowly and it takes longer for the water to become 'clean' in the days following heavy rains.

Alterations to the waters were more intense in the first few years. However, the Tembe state that the decrease in quality first observed has not been reverted, especially the loss of flow and level of the streams which are now lower in both dry and rainy seasons 
than they used to be. They called for water analyses to be made but there have been few and they did not test for the presence of toxic agrochemicals.

According to Tembé leaders, in the early years of the oil palm venture, part of the stream headwaters dried up while others became intermittent. That apparent oscillation may be a cause for concern in the context of climate change insofar as the predictions for the Amazon region foresee more frequent droughts (DUFFY et al., 2015). Interviews in the field and documental data indicate that some of the springs and headwaters are bordered by a gallery forest vegetation strip that is narrower than the mandatory 50 meters required by the Brazilian Forest law, which means that in some cases the plantation extends inside Permanent Protection Areas (PPAs) (FUNAI, 2014).

Data extracted from the Tembé narrative associated to those obtained from the remote sensing indicate that field diagnoses for the mapping of PPAs need to be a mandatory part of the licensing process prior to and after the installation of large-scale oil palm plantations and land conversion to that end. That would orientate the planning for the occupation of the land in such a way as to avoid the removal of native vegetation and planting inside protected areas, in addition to foster the adoption of forest restoration strategies.

Recently it has been discovered that small streams make up as much as $80 \%$ of the extension of some Amazonian river basins and shelter a high degree of biodiversity (LEAL; LEITÃO, 2016). Furthermore, Leal et al. (2017) question the efficacy of the current governance approach merely focusing on the protection of riparian vegetation nearby PPAs and suggest that conservation actions should embrace a larger scale and pay more attention to the practices adopted in private areas opened up for agriculture.

\section{Emergence of health problems - "That water, it's itchy"}

After the implantation of monoculture oil palm cultivation in the lands around their IT, the Tembe began to experience health problems. Intestinal pains, diarrhea, vomiting, headaches, fever and itchy skin affected the population in general and led to public protests in the years following the planting stage (ÍNDIOS, 2012).

The occurrence of diseases is associated to a set of changes in which the degradation of the streams seems to have been the most influential. The symptoms experienced by the villagers are by no means an isolated case. Residents of other communities near to oil palm monoculture plantations in neighboring municipalities have reported similar symptoms also associated to contact with water (GLASS, 2013).

The Tembé observed that the symptoms began to appear after the applications of fertilizer and toxic agrochemicals. The sicknesses became more acute in the rainy season, especially in the early years of cultivation that coincide with the more intensive use of agrochemicals during the initial growing stage of the palms during, which the quantities applied and the frequency of applications are greater (GOMES JUNIOR, 2010). Two of the Tembé women described it as follows: 
We felt it in the stream right away, especially in the rainy season because whatever chemicals they applied there, fertilizers and such, came in, washed down. At that time, we used to use the stream. We drank water, all from the stream. So then nearly everyone got belly ache $(. .$.$) because they drank xibé e^{4}$ or bathed there and drank water from the stream.

At the time the Health Center couldn't handle it. The doctor merely wrote out a prescription and we had to buy it ourselves. It was a case of little skin blisters full of liquid. Not just a few, oh no. Many, many blisters. They were itchy (...) terribly itchy (...) he [a little boy now 7] was small and did not know how to scratch himself like us adults. We looked at him; it was as if he had changed his skin. Little sores all over him. The first time he got it, it lasted for about three or four months; a strong itching. When it broke out a second time it was in all those who had been stubborn enough to go there and bathe.

The Tembe report that in the first years of the plantation installation, the symptoms appeared in a generalized manner in the various villages. In the Indigenous Health Information System (Sistema de Informação da Saúde Indígena - Siasi/Sesai/MS) despite the high rate of sub-notification, it is possible to verify the concentration of cases of skin problems in the period 2011 and 2012; that is, right after the planting of the first large area. One health agent describes the health care provision in that period in the following terms:

\begin{abstract}
About one year after the planting there were many complaints of skin diseases and headaches. That was fairly intense for about six months, then it began to go down. Many of the headaches were associated to people with sight problems but in many other cases (...) there was no evident cause. In 2005, [prior to the planting] the rate of skin diseases, diarrhea, colds and headaches was practically zero.
\end{abstract}

In the records for 2016 there were registrations of cases of itching, skin rashes, diarrheas, and headaches but less intense, and sporadic rather than generalized. In 2014 there had been 48 health consultations in the villages classified under the heading 'pain', according to the Siasi/Sesai/MS.

I have headaches, my son has them (...). All these children have

4- A cassava (manioc) meal (farinha) moistened with stream water and consumed with smoked game meat. 
them. It is not normal for a child to have headaches. I can remember that before it used to be rare. Here now, it is constant. Every now and then I hear one of the children saying: 'I've got a headache'. Children just 12, just 7 years old (Tembé woman).

\section{Environmental contamination risk}

In the Tembe discourse, the relations of causality established between the set of diseases that appeared and the use of toxic agrochemicals and fertilizers in the plantations around the IT are based on the following elements: the concomitance of the appearance of the symptoms and the start of the applications of toxic agrochemicals and fertilizers; ii) the alterations to the waterbodies such as their color and smell which were accentuated in the rainy season after spraying activities when oil, foam and a strange rusty-colored substance were observed on the water surface (Figure 5); iii) the appearance of symptoms in those people who most used the streams to bathe or to drink from; and iv) the numbers of wild animals found dead in the streams and in the vegetation in the areas surrounding the IT.

The perception of environmental contamination appears in the narratives in two ways. There is recurrent reference to the waters associated to terms such as 'polluted', 'intoxicated' 'rusty' and 'contaminated'. In a second perspective, however, they reveal their uncertainty and fear in regard to the extent of the supposed contamination and its permanence in the environment - whether it will be restricted to the periods of application of those agricultural inputs, or not and the risk of the substances accumulating in the animals they eat and the harm that could cause to their health.

\section{The Tembe's relationship with the waters before and after the advent of the oil palm}

Prior to the advent of oil palm cultivation in the region, the streams were the main source of access to water, complemented by a few shallow wide-rimmed wells and a single artesian well in the village of Teknay. The Tembé explain their preference for the stream water saying that it is 'nice and cool' and flowing. Generally speaking, children and adults would be in contact with water several times a day, to cool off in collective bathing, to wash clothes and utensils or to prepare food. However, nowadays, they avoid traditional activities such as gathering beside the stream to prepare xibé.

Given the frequent health problems associated to drinking or bathing in the stream water, wells are gaining more popularity. In the fieldwork it was possible to identify six wells in use albeit there are still some families that capture their water directly from the streams (Figure 5). Four of the five artesian wells that supply the villages were bored after the areas had been converted into oil palm plantations. That movement [to implant wells] coincided with the reduction in the use of the streams.

However important the construction of wells may be to these people, it cannot supplant the services the streams provide such as food, recreation and cultural practices. 
They are at the base of collective social activities that are part of Tembe culture and reinforce their bonds with the land and the natural environment.

Figure 5 - (A) The Turé stream in the IT during the dry season, shallow and with yellowish water; (B) and with water up to the children's waists in the rainy season (different angle from the same spot); (C) Children playing in the stream of the Teknay village. On the right, a pipe for capturing water from the stream which is consumed by the respective family; (D) Presence of a sandbank and an orange-colored substance on the soil and the surface of the Breuzinho stream.
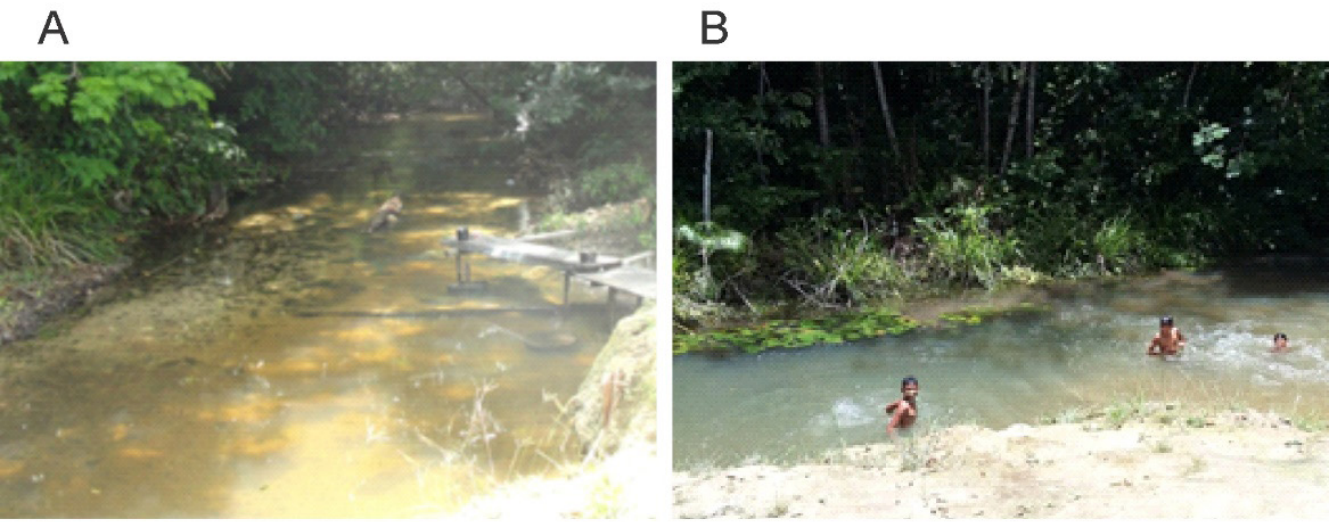

C

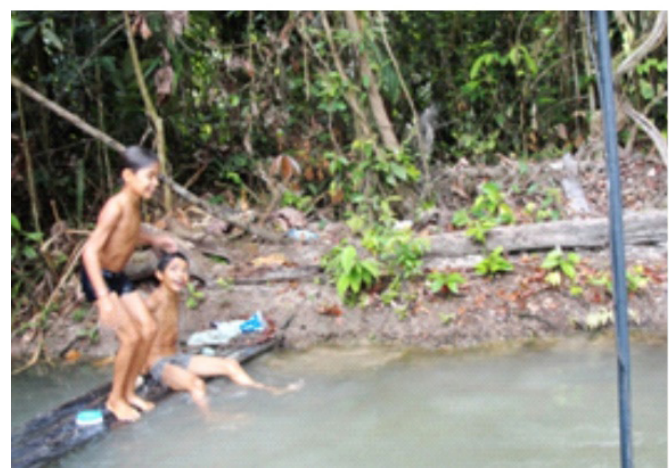

D

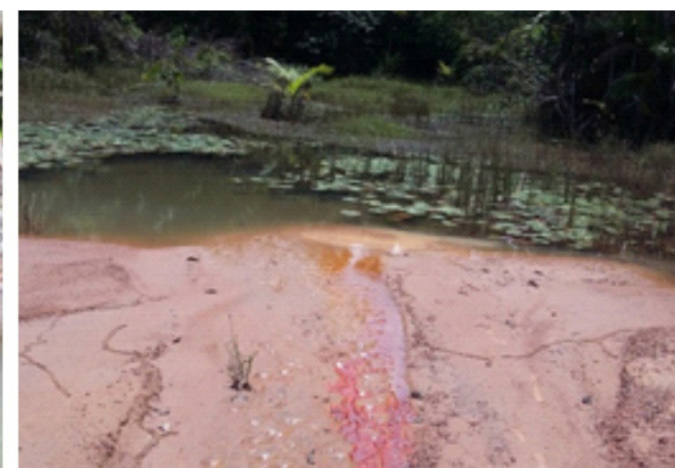

Source: Research images.

Proliferation of snakes and insects - "The oil palm attracts a lot of insects, brings a lot of snakes"

The Tembé identify the proliferation of insects and snakes as being one of the impacts stemming from the monoculture of oil palm. After the planting stage they began to appear in what they considered to be atypical numbers and amounts in the villages and with greater intensity in the period 2014 to 2016. The snakes are noted not only for 
their abundance, but also their frequent contact with the population in places such as patios, fields and even inside the houses. The presence of great quantities of insects is not continuous but more of a sporadic occurrence.

The indigenous people consider that the increase in the snake population is due to the loss of native vegetation in the lands surrounding the IT and the great number of rodents in the oil palm areas. Studies in the Brazilian Amazon and in Colombia show that some mammal species and snakes are found in higher population densities in the oil palm plantations than those registered for forests (MENDES-OLIVEIRA, 2015; LYNCH, 2015).

The oil palm cultivation practices include cutting the older leaves and leaving them to cover the ground in the lines between the plants. According to how much they accumulate on the ground they can give rise to increases in insect populations and foster the formation of nests by rats and a proliferation of snakes (FURLAN JÚNIOR, 2006).

That proliferation of vectors and poisonous snakes, in addition to be a considerable nuisance, can also pose a health risk. The nearest health care installation, the Indigenous Primary Healthcare Clinic, is about $30 \mathrm{~km}$ from the IT; a journey of about one hour over a dirt road in very bad condition and generally made by car or motorbike. When there is no anti-snake serum at the clinic the patient needs to be removed to the state capital and so the risk of permanent harm or death is so much greater.

Before you would hardly ever hear that someone had been bitten by a snake. Last year there were about five incidents. Before there were snakes but you hardly saw them. What we saw more was the jiboia (a land boa), the others, they were all in the forest. Now they come right inside the house (Tembé woman).

Increase in local temperatures - "The oil palm... it's hot"

There is a generalized perception that the local climate in the surrounding areas and in the villages themselves has 'changed a lot". The 'quentura' (warmth) as they call it, started after the establishment of the oil palm plantations. Among the various ecosystem services that forests provide are regulation of the micro-climate in adjacent areas (SILVÉRIO et al., 2015). While the Turé-Mariquita IT context points to the need for specific studies, the hypothesis of alterations to that thermal regulation service is consistent with the collective affirmation that a rise of temperature occurred after the suppression of the native vegetation in the lands surrounding the IT and the villages. The declarations of two Tembé women suggest the existence of that association:

"Here, near to the village, it was all high thicket vegetation, almost forest really. The trees were already quite big (...) it has all been cleared. Now there is only oil palm, and it is very hot."

"Sometimes when the wind blew, it was that nice cool breeze. Now it is a hot wind. (...) I think it was due to the deforestation that took place over there." 
The perception that, compared to the natural forest vegetation, the oil palm plantation is 'hot' is corroborated by studies in Asian countries. In Malaysia, the temperatures in the oil palm plantations was found to be $2.8^{\circ} \mathrm{C}$ higher than in the tropical forest (LUSKIN; POTTS, 2011). In Borneo, Hardwick et al. (2015) registered temperatures $4^{\circ} \mathrm{C}$ higher in the oil palm plantations than in the secondary vegetation formations and $6.5^{\circ} \mathrm{C}$ higher than in the primary forests. Both studies found that the soils were drier and there was less humidity in the air in the oil palm plantations. In the village areas the Tembé observe that the soil is drier and that has forced them to adapt their agricultural practices.

One indigenous individual with a field bordering on the oil palm areas describes it as follows:

It was ever since the machines came in, wasn't it? All the vegetation was cleared... things started to change a lot. We could see that the plants we used to plant would resist the dry season with no need to be watered, no need for mulch, but not now. We planted [black] pepper. The plants resisted the dry season without mulch and without watering but now, if we don't mulch them everything dies.

Our data reveal the need for complementary studies to explore the influence of forest fragments on climate, on indigenous small-scale lands set in the midst of anthropized surroundings, and to investigate how monoculture cultivations bordering protected areas can affect the local microclimate, soil and hydrological regimes.

Local climate changes make indigenous lands more vulnerable to global climate change and scenario analyses forecast a tendency for droughts to be more severe and occur more frequently in the Amazon region in the coming decades (DUFFY et al., 2015). For researchers such as França et al. (2020), the effects of interactions between local stress factors, such as the Tembé describe, and climate change will bring about unprecedented ecological alterations to tropical forests caused by the impacts on biodiversity and the reduction in the resilience of the ecosystems.

Indigenous peoples are already feeling the effects of climate change throughout Brazil and it is becoming a present and long-term challenge to the environmental and territorial administration of Indigenous Territories (DOURADO et al., 2017). That scenario underscores the role of instruments associated to the National Policy on the Territorial and Environmental Administration of Indigenous Territories (Política Nacional de Gestão Territorial e Ambiental de Terras Indígenas - PNGATI) (BAVARESCO; MENEZES, 2014) so that IT planning can incorporate an inter-scale perspective that takes into account not only the demarcated physical space but also the transformations and the land use patterns in the extended territory.

\section{Final Considerations}

The results obtained from the analysis of the Tembé narrative reveal their perception 
that the changes in land use in the areas converted to oil palm monoculture plantations surrounding the Turé-Mariquita IT, and around the two adjacent villages, have negatively affected their way of life and their wellbeing. The remote sensing data regarding the suppression of secondary vegetation corroborate the data presented by the Tembe in their identification of the loss of secondary [forest] vegetation in the surrounding areas.

It is suggested that the other perceived socio-environmental impacts, supported to some extent by the scientific literature, should be investigated using specific complementary methods for the phenomena described in this article. In that sense, it must be underscored that multi-disciplinary approaches such as the one adopted in this research are most appropriate when the intention is to obtain a holistic understanding of the socio-environmental problems and of the way they pressure the socio-ecological systems. The results indicate fields of research that other sciences could venture into, such as investigations into fauna, climate and the presence of oil palm plantations, as well as public health studies. Given the scarcity of studies regarding the impact of oil palm cultivation on indigenous peoples, the present research most certainly makes an unprecedented contribution.

The results also suggest the potential risks associated to the implantation of extensive palm oil plantations in areas surrounding indigenous lands, currently considered to be of low impact, definitely need to be reassessed. The loss of environmental quality narrated by the Tembé exposes the need for a discussion of restrictive legislation in regard to proximity of oil palm plantation ventures and indigenous peoples, in addition to other kinds of traditional communities with close relations of dependency on natural resources, and, accordingly, vulnerable to alterations in socio-environmental patterns.

\section{Acknowledgements}

The first author thanks the Tembé for sharing their experiences and for receiving her in their homes and villages; thanks go to the CNPq for the MSc research fellowship and to the FAPDF for supporting the technical visit. The authors wish to thank the Funai CT Tomé Açu.

\section{References}

ANGROSINO, M. Etnografia e observação participante. Porto Alegre: Artmed, 2009. 138p. (Coleção Pesquisa Qualitativa).

BAVARESCO, A.; MENEZES, M. Entendendo a PNGATI: Política Nacional de Gestão Territorial e Ambiental Indígenas. - Brasília: GIZ/Projeto GATI/Funai, 2014.

BENAMI, E. et al. Oil palm land conversion in Pará, Brazil, from 2006-2014: evaluating the 2010 Brazilian sustainable palm oil production program. Environmental Research Letters, v. 13, 
n. 3, p. 034037, 2018.

CARNEIRO DA CUNHA, M. 2009. "Relações e dissensões entre saberes tradicionais e saber científico”. In: Cultura com aspas e outros ensaios. SP: Cosac \& Naify.

CARVALHO, C. M. de. et al. Deforested and degraded land available for the expansion of palm oil for biodiesel in the state of Pará in the Brazilian Amazon. Renewable and Sustainable Energy Reviews, v. 44, p. 867-876, 2015.

CODEC - Companhia de Desenvolvimento Econômico do Pará. Invest Pará, 2020. Licenciamento Ambiental Simplificado.

Disponível em: <http://investpara.com.br/licenciamento-ambiental-simples-ambiental/> Acesso em: 05 abr. de 2020.

COEMA - Conselho Estadual de Meio Ambiente. Resolução ad referendum № 127 de 18 de novembro de 2016. Belém, PA, 2016.

CORREA, F. S. et al. Effects of oil palm plantations on anuran diversity in the eastern Amazon. Animal Biology, v. 65, n. 3-4, p. 321-335, 2015.

DOURADO, M. F. et al. A gestão ambiental e territorial de Terras Indígenas da Amazônia brasileira: uma questão climática. Brasiliana-Journal for Brazilian Studies, v. 5, n. 1, p. 230-253, 2017.

DUFFY, P. B. et al. Projections of future meteorological drought and wet periods in the Amazon. Proceedings of the National Academy of Sciences, v. 112, n. 43, p. 13172-13177, 2015.

EDWARDS, D. P. et al. Degraded lands worth protecting: the biological importance of Southeast Asia's repeatedly logged forests. Proceedings of the Royal Society of London B: Biological Sciences, v. 278, n. 1702, p. 82-90, 2011.

FAPESPA - Fundação Amazônia de Amparo a Estudos e Pesquisas do Pará. Boletim Agropecuário do estado do Pará 2017. Belém, PA. 2017. 38p. Disponível em: < http://www.fapespa.pa.gov. br/upload/Arquivo/anexo/1383.pdf?id=1533567716> Acesso em 05 jul 2018.

FRANÇA, F. M. et al. Climatic and local stressor interactions threaten tropical forests and coral reefs. Philosophical Transactions of the Royal Society B, v. 375, n. 1794, p. 20190116, 2020.

FUNAI - Fundação Nacional do Índio. Documento interno. Relatório de atividade. Diagnóstico das implicações da cultura do dendê sobre a Terra Indígena Turé-Mariquita e Aldeia Arumateua no Município de Tomé-Açu, Estado do Pará [documento interno]. Belém, PA, 2014.

FUNAI - Fundação Nacional do Índio. Censo sociodemográfico da população Tembé em Tomé-Açu [documento interno]. Belém/PA, 2017.

FURLAN JÚNIOR, J. Dendê: manejo e uso dos subprodutos e dos resíduos. Embrapa Amazônia Oriental-Documentos (INFOTECA-E), 2006. 
GLASS, V. Expansão do dendê na Amazônia Brasileira: elementos para uma análise dos impactos sobre a agricultura familiar no nordeste do Pará. Centro de Monitoramento de Agrocombustíveis. ONG Repórter Brasil. São Paulo, Brasil; 2013.

GOMES JUNIOR, R. A (org). Bases técnicas para a cultura da palma de óleo integrado na unidade produtiva da agricultura familiar. Belém, PA: Embrapa Amazônia Oriental, 2010.

GRIMALDI, M. et al. Ecosystem services of regulation and support in Amazonian pioneer fronts: searching for landscape drivers. Landscape ecology, v. 29, n. 2, p. 311, 2014.

HARDWICK, S. R. et al. The relationship between leaf area index and microclimate in tropical forest and oil palm plantation: Forest disturbance drives changes in microclimate. Agricultural and Forest Meteorology, v. 201, p. 187-195, 2015.

ÍNDIOS mantém funcionários de empresa reféns em Tomé-Açu, PA. G1 PA. Belém, 17 maio. 2012. <Disponível em: http:/g1.globo.com/pa/para/noticia/2012/05/indios-mantem-funcionarios-de-empresa-refens-em-tome-acu-pa.html> Acesso em 02 jun 2017.

LAURANCE, W. F. et al. The fate of Amazonian forest fragments: a 32-year investigation. Biological conservation, v. 144, n. 1, p. 56-67, 2011.

LEAL, C.G. et al. Is environmental legislation conserving tropical stream faunas? A large $\square$ scale assessment of local, riparian and catchment $\square$ scale influences on Amazonian fish. Journal of Applied Ecology, 2017.

LEAL, C. G; LEITÃO, R. P. Pequenos gigantes (Igarapés amazônicos em paisagens antropizadas). Policy Brief. Rede Amazônia Sustentável, 2016.LEES, A. C. et al. Poor prospects for avian biodiversity in Amazonian oil palm. PloS one, v. 10, n. 5, p. e0122432, 2015.

LYNCH, J. D. The role of plantations of the african palm (Elaeis guineensis Jacq.) in the conservation of snakes in Colombia. Caldasia, v. 37, n. 1, p. 169-182, 2015.

LITTLE, P. E. Environments and environmentalisms in anthropological research: facing a new millennium. Annual Review of Anthropology, v. 28, n. 1, p. 253-284, 1999.

LUSKIN, M. S.; POTTS, M. D. Microclimate and habitat heterogeneity through the oil palm lifecycle. Basic and Applied Ecology, v. 12, n. 6, p. 540-551, 2011.

MADDOX, T. The Conservation of Tigers and Other Wildlife in Oil Palm Plantations: Jambi Province, Sumatra, Indonesia (October 2007). Zoological society of London (ZSL), 2007.

MENDES-OLIVEIRA, A. C. et al. Efeitos antrópicos sobre comunidades de pequenos mamíferos não-voadores na Amazônia brasileira. In: MENDES-OLIVEIRA, A. C.;

MIRANDA, C. Os Pequenos Mamíferos Não Voadores da Amazônia Brasileira. Publisher: Sociedade Brasileira de Mastozoologia-Serie Livros 2, 2015. Cap 8, p.257-274.

MILTON, K. (Ed.). Environmentalism: the view from anthropology. London; New York: 
Psychology Press, 1993.

MINAYO, M. C. de S. (org.). Pesquisa social: teoria, método e criatividade. 29. ed. Petrópolis, RJ: Vozes, 2010.

MOURA, N. G. et al. Avian biodiversity in multiple-use landscapes of the Brazilian Amazon. Biological Conservation, v. 167, p. 339-348, 2013.

MOTA, D. M. da; RIBEIRO, L.; SCHMITZ, H. A organização do trabalho familiar sob a influência da produção de dendê em Tomé-Açu, Pará. Boletim do Museu Paraense Emílio Goeldi. Ciências Humanas, 2019, 14.2: 531-552.

MPF - Ministério Público Federal. Procuradoria da República no Estado do Pará. Ação cautelar de antecipação de prova com pedido de liminar. Processo n. 29245-40.2014.4.01.3900. Belém, PA, nov 2014.

NAHUM, J. S., \& SANTOS, C. B. dos. (2017). DO SÍTIO CAMPONÊS AO LOTE DE DENDÊ: TRANSFORMAÇÕES DO ESPAÇO RURAL NA AMAZÔNIA PARAENSE NO SÉCU. LO XXI. REVISTA NERA, (37), 54-76.

NAHUM, J. S.; THURY, J. P. C. ENCONTROS E DESENCONTROS NA AMAZÔNIA PARAENSE: os Tembés-Turê-Mariquita e a Biopalma em Tomé-açu (PA). InterEspaço: Revista de Geografia e Interdisciplinaridade, v. 1, n. 3, p. 82-96, 2015.

OBIDZINSKI, K. et al. Environmental and social impacts of oil palm plantations and their implications for biofuel production in Indonesia. Ecology and Society, v. 17, n. 1, 2012.

PARÁ PIGMENTOS S.A. Diagnóstico Etnoambiental dos grupos Tembé e AIs Tembé, Ture-Mariquita e Urumateua de Tomé-Açu (PA): Relatório Técnico [documento interno]. Vitória: Cepamar, 1995. 154 p.

PARRY, L.; BARLOW, J.; PERES, C. A. Large-vertebrate assemblages of primary and secondary forests in the Brazilian Amazon. Journal of Tropical Ecology, v. 23, n. 6, p. 653-662, 2007.

PEIRANO, M. Etnogradia ou teoria vivida. Ponto Urbe, volume 2, 2008.

SABOURIN, E. Métodos qualitativos em ciências sociais: Observação Participante. Quartas Metodológicas. Centro de Desenvolvimento Sustentável, CDS. Maio, 2016.

SÁNCHEZ, L. E. Avaliação de impacto ambiental: conceitos e métodos. 2. ed. atual. amp. São Paulo: Oficina de Textos, 2013. 583 p.

SILVÉRIO, D. V. et al. Agricultural expansion dominates climate changes in southeastern Amazonia: The overlooked non-GHG forcing. Environmental Research Letters, v. 10, n. 10, p. $104015,2015$.

SOARES-FILHO, B. S. et al. Cenários de desmatamento para a Amazônia. Estudos Avançados, v. 19, n. 54, p. 137-152, 2005. 
VIEIRA, I. C. G. et al. Challenges of governing second-growth forests: A case study from the Brazilian Amazonian State of Pará. Forests, v. 5, n. 7, p. 1737-1752, 2014.

VIJAY, V. et al. The impacts of oil palm on recent deforestation and biodiversity loss. PloS one, v. 11, n. 7, p. e0159668, 2016.

VILLELA, A. A. et al. Status and prospects of oil palm in the Brazilian Amazon. Biomass and Bioenergy, v. 67, p. 270-278, 2014.

WILCOVE, D. S.; KOH, L.P. Addressing the threats to biodiversity from oil-palm agriculture. Biodiversity and Conservation, v. 19, n. 4, p. 999-1007, 2010. 


\section{Sandra Damiani}

■sandra_damiani@hotmail.com

ORCiD: https://orcid.org/0000-0003-4310-3766
Submitted on: $28 / 06 / 2019$

Accepted on: $31 / 08 / 2020$

2020;23:e00492

\section{Sílvia Maria Ferreira da Silva}

ロ silviag@unb.br

ORCiD: https://orcid.org/0000-0002-2097-2355

\section{Maria Tereza Leite Montalvão}

$\square$ maitegisbackup@gmail.com

\section{Carlos José Sousa Passos}

$\square$ cjpassos@unb.br

ORCiD: https://orcid.org/0000-0002-0553-9342

How to cite: DAMIANI, S.; SILVA, S. M. F. da.; MONTALVÃO, M. T. L.; PASSOS, C. J. S. All That's Left is Bare Land and Sky": Palm Oil Culture and Socioenvironmental Impacts on a Tembé Indigenous Territory in the Brazilian Amazon. Ambiente $\&$ Sociedade. São Paulo, v. 23, p. 1-16, 2020. 


\title{
"Ficou só Chão e Céu": Dendeicultura e Impactos Socioambientais sobre Território Tembé na Amazônia
}

\author{
Sandra Damiani \\ Silvia Maria Ferreira Guimarães \\ Maria Tereza Leite Montalvão \\ Carlos José Sousa Passos
}

São Paulo. Vol. 23, 2020

Artigo Original
Resumo: A expansão do cultivo de dendê em larga escala na Amazônia Brasileira expôs populações indígenas a rápidas transformações no entorno de suas terras e nas atividades diárias em seu território. Diante da escassez de estudos empíricos sobre impactos da dendeicultura nestas populações, esta pesquisa analisou os impactos socioambientais percebidos pelos Tembé, em Tomé-Açu (PA). Com uma metodologia interdisciplinar, conduziram-se, entre 2016 e 2017, entrevistas semiestruturadas e observação participante em cinco aldeamentos, dentro e adjacentes à Terra Indígena Turé-Mariquita (TI), complementadas por análises de sensoriamento remoto. Descrevem-se os vetores de pressão e os principais impactos socioambientais pela análise da narrativa indígena, e, posteriormente, estes são discutidos com base na literatura científica e de sensoriamento remoto. Os achados indicam que a conversão do território de entorno para monocultura de dendê gerou alterações sociais e ambientais que afetaram negativamente o modo de vida e a capacidade de reprodução sociocultural dos Tembé.

Palavras-chave: Impactos socioambientais, dendê, Terra Indígena, índios Tembé, Amazônia.

Como citar: DAMIANI, S.; SILVA, S. M. F. da.; MONTALVÃO, M. T. L.; PASSOS, C. J. S. "Ficou só Chão e Céu": Dendeicultura e Impactos Socioambientais sobre Território Tembé na Amazônia. Ambiente $\mathbb{E}$ Sociedade. São Paulo, v. 23, p. 1-24, 2020. 


\title{
"Solo nos Quedó la Tierra Desnuda y el Cielo": Cultivo de Palma de Aceite e Impactos Socioambientales en el Territorio Tembé en la Amazonia Brasileña
}

\author{
Sandra Damiani \\ Sílvia Maria Ferreira Guimarães \\ Maria Tereza Leite Montalvão \\ Carlos José Sousa Passos
}

São Paulo. Vol. 23, 2020

Artículo original
Resumen: La expansión del cultivo de palma aceitera a gran escala en la Amazonía expuso a las poblaciones indígenas a cambios en los alrededores de sus tierras y en sus actividades diarias. Dada la falta de estudios sobre los impactos de la palma en estas poblaciones, nosotros analizamos los impactos socioambientales percibidos por los Tembé, en Tomé-Açu (PA). Con una metodología interdisciplinaria, entre 2016 y 2017 realizamos entrevistas semiestructuradas y observación participante en cinco aldeas, dentro y adyacentes a la Tierra Indígena Turé-Mariquita, complementadas con análisis de teledetección. Describimos los vectores de presión y principales impactos socioambientales gracias al análisis de la narrativa indígena. Ambos son discutidos basándonos en la literatura científica y datos de teledetección. Los resultados indican que la conversión del territorio a monocultivos generó cambios sociales y ambientales que afectaron negativamente la forma de vida y la capacidad de reproducción sociocultural de los Tembé.

Palabras-clave: Impactos socioambientales, palma, Tierra Indígena, indios Tembé, Amazonia.

Como citar: DAMIANI, S.; SILVA, S. M. F. da.; MONTALVÃO, M. T. L.; PASSOS, C. J. S. "Solo nos Quedó la Tierra Desnuda y el Cielo": Cultivo de Palma de Aceite e Impactos Socioambientales en el Territorio Tembé en la Amazonia Brasileña Ambiente $\mathbb{\&}$ Sociedade. São Paulo, v. 23, p. 1-24, 2020. 